RESEARCH ARTICLE

\title{
Cascade of Care for HIV Positive Patients in a Rural Health Region in the North-Central Region of Ivory Coast: A Follow-up Study
}

\author{
Ehui Eboi, Bashi Jules, Kouakou A. Gisele, Kassi N. Alain, Mossou C. Chrysostome, Doumbia Adama, \\ Tanon K. Aristophane, Eholié S. Paul
}

Service des Maladies Infectieuses et Tropicales, CHU de Treichville; Abidjan, Côte d'Ivoire

\begin{abstract}
Objective: To describe the cascade of care for HIV positive patients in the health region of Worodougou-Béré, NorthCentral Region of Ivory Coast.
\end{abstract}

Methods: Cross-sectional study which included patients diagnosed HIV positive between January 2009 and December 2012 was conducted. The analysis focused on different steps of care, from HIV screening to antiretroviral treatment (ART) initiation.

Results: A total of 1659 people were diagnosed HIV positive and $992(60 \%)$ of them were included in HIV care. Their median age and CD4 count were 33 years [27-41 years] and 311 cells $/ \mathrm{mm} 3\left[162-548 / \mathrm{mm}^{3}\right]$, respectively. Overall, $55 \%$ of them were female and $62 \%$ were symptomatic. The proportion of eligible patients was $52 \%$, and $81 \%$ of them started ART.

Conclusion: The cascade of HIV care in Worodougou-Béré Region had high attrition rate. A change in strategy, included point of care CD4 and viral load, is needed to increase access to ART and retention in care in these rural areas. J Microbiol Infect Dis 2017; 7(3):144-147

Keywords: Attrition, cascade, HIV, point of care, rural area

\section{INTRODUCTION}

Antiretroviral treatment was implemented in Ivory Coast in 1998 with the support of UNAIDS through the Drugs Access Initiative (DAI) [1-3]. In Côte d'Ivoire, HIV treatment and care have been decentralized since 2004 through the integration of HIV activities in the minimum healthcare package of health facilities. ART and follow-up monitoring have been free of charge for people living with HIV/AIDS (PLWHA) since 2008. In 2010, more than 400 public health facilities across the country provided care to PLWHA [4]. Use of ART has improved the life expectancy of PLWHA. However, morbidity and mortality remained high during the first year of ART implementation with respective frequencies of $5-10 \%$ person-year (PY) and $2-3 \%$ PY. Morbidity was mainly related to infectious disease (tuberculosis and bacteremia) and earlier onset of adverse events (AE) [5]. All these data come from studies carried out for most of them in Abidjan, and also showed a significant number of patients lost to follow-up. Very few studies have focused on these antiretroviral treatment activities in rural regions of Côte d'Ivoire. The purpose of our study was to describe the cascade of care for HIV positive patients in the health region of WorodougouBéré, North-Central region of Ivory Coast.

\section{METHODS}

\section{Study type}

A cross-sectional study was conducted in 13 health facilities of Worodougou-Béré Region, and included patients diagnosed HIV positive between January 2009 and December 2012.

\section{Study site}

The health region of Worodougou-Béré is a semi-rural area in the north-central region of Côte d'Ivoire, covering a surface area of 22000 $\mathrm{km} 2$, with an estimated population of 500,000 inhabitants. It has two health districts (Mankono and Séguéla that are $521 \mathrm{~km}$ and $592 \mathrm{~km}$ from 
Abidjan respectively) and 52 health facilities of which 14 provide care for HIV positive patients. Blood samples for pre-treatment laboratory tests were transported from health centres to the two laboratories in the region once a week. The viral load test was not available at the time of the study.

\section{Study population}

All HIV-infected patients regardless of age, diagnosed between 1st January 2009 and 31st December 2012, who were enrolled in care after HIV screening and had performed at least two follow-up visits in one of the 13 health facilities of the Worodougou- Béré Region, were included. Patients initiated antiretroviral treatment (ART) according to national algorithm: disease of WHO stage 4 regardless of CD4 cell count or a CD4 cell count $\leq 200$ cells $/ \mathrm{mm}^{3}$ (until December 2009), then CD4 $\leq 350$ cells $/ \mathrm{mm}^{3}$ or WHO stage 4 . The first-line treatment provided free of charge to patients contained efavirenz or nevirapine combined with zidovudine or tenofovir and lamivudine [6,7]. The follow-up consisted of a quarterly clinical examination and laboratory tests performed each semester.

\section{Data collection}

Socio-demographic (age, gender), clinical (weight, CDC clinical stage), biological (type of HIV, CD4 count, haemoglobin level) and therapeutic data were extracted from the electronic database of each centre and analysed using the SPSS Statistics software (version 19). Consistency between ART prescriptions and the applicable national guidelines was assessed based on ART eligibility criteria (clinical and immunological) at the time of the study. The prescription was deemed consistent if it met $100 \%$ the national guidelines. The national ethics committee of Ivory Coast gave an ethical approval for the use of all routinely collected data for the care and management of HIVpositive patients followed in health facilities of the Worodougou- Béré region.

\section{RESULTS}

From January 2009 to December 2012, 1659 out of 44,821 tested patients were diagnosed HIV positive (3.7\%), of whom 992 (59.8\%) were enrolled in HIV care. Their median age and CD4 count were 33 years [27-41 years] and 311 cells $/ \mathrm{mm}^{3}$ [162-548 cells $\left./ \mathrm{mm}^{3}\right]$. Overall, $3 \%$ of patients were under 15 years of age and the $M / F$ sex ratio was 0.46 . The proportion of symptomatic patients (clinical stages B and $\mathrm{C}$ ) was $62 \%$ and median hemoglobin level of 9.9 $\mathrm{g} / \mathrm{dl}[8.5$ to $11.6 \mathrm{~g} / \mathrm{dl}]$ (Table 1$)$. The laboratory tests were performed in 609/992 patients (37\%) over an average period of five days, of whom 515 patients $(84.6 \%)$ were eligible for ART. Finally, 1050 out of the 1659 tested patients $(63.3 \%)$ were lost to follow-up before antiretroviral treatment initiation, and 418 only patients received first-line ART (Figure I). At the time of the study, 86 patients with less than 200 $\mathrm{CD} 4 / \mathrm{mm}^{3}$ did not start antiretroviral therapy, whereas 31 patients not eligible according to national guidelines were treated. Twenty-two of the 418 treated patients received first-line ART regimens not consistent with national guidelines (Table 2).

Table 1. Demographics, clinical and biological characteristics of the patients enrolled in HIV care in the health region of Worodougou-Béré between 2009 and 2012 ( $N=992)$.

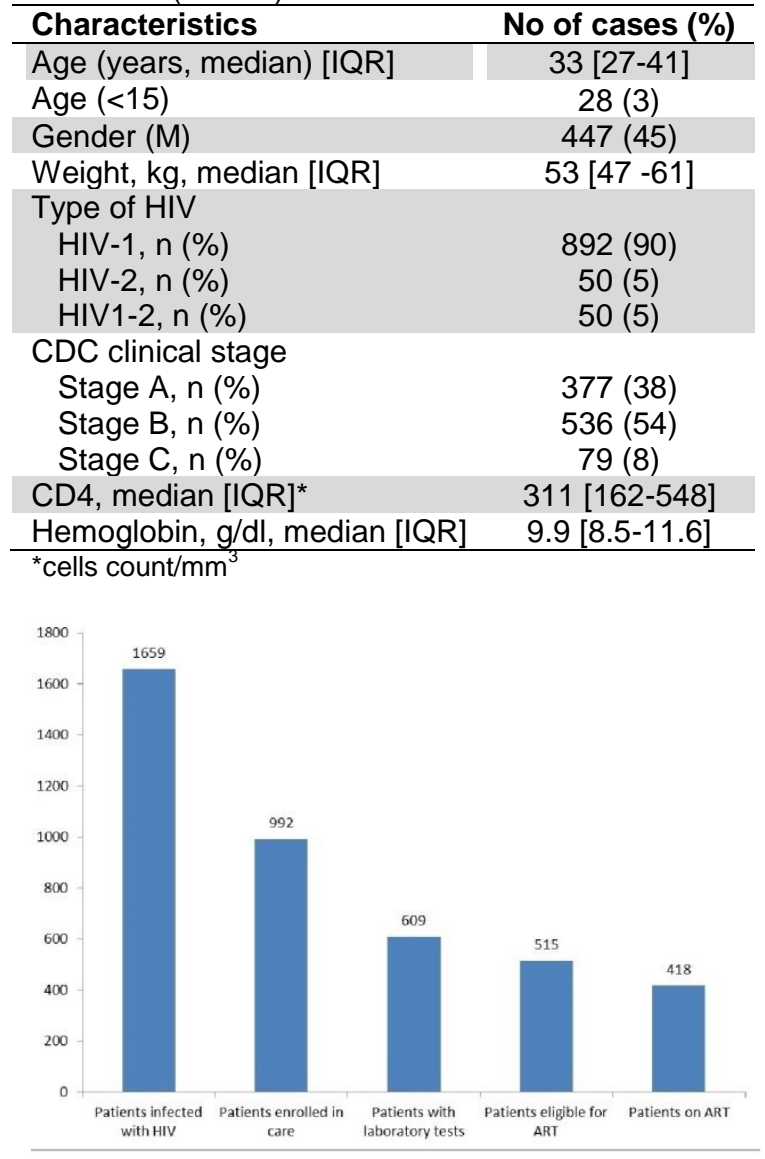

Figure 1: Cascade of care for HIV-infected patients enrolled between 2009 and 2012 in the health region of Worodougou-Béré. 


\section{DISCUSSION}

This study, the first in Ivory Coast, enabled us to assess the widespread access to ART in rural areas. Its retrospective nature and the lack of viral load testing did not made it possible to assess the level of patient adherence to treatment, retention in care rates and viral suppression as in Nosyk et al. study [8]. Our study population's socio-demographic and clinical profile was identical to that found in many studies conducted in Africa [9-12]. Indeed, it was a young, predominantly female population that was more frequently symptomatic but with relatively higher CD4 counts. In our study, at least $81 \%$ of eligible patients started antiretroviral triple therapy, which is a higher rate than that of Govindasamy et al study [13], but below the UNAIDS 90-90-90 target [14].

Table 2. Compliance of therapeutic prescriptions to national guidelines for initiation of antiretroviral treatment in the health region of Worodougou-Béré between 2009 and 2012.

\begin{tabular}{lc}
\hline Parameters & 86 \\
\hline Patients with CD4 <200 cells $/ \mathrm{mm}^{3}$ not on ART & $31(6 \%)$ \\
Proportion of HIV-infected patients not eligible, but on ART (N=94) & 12 \\
$\quad$ CDC clinical Stage A (with CD4 $>350$ cells $/ \mathrm{mm}^{3}$ ) & 19 \\
CDC clinical Stage B (with CD4 $>500$ cells $/ \mathrm{mm}^{3}$ ) & 22 \\
Proportion of HIV infected patients on ART with combination not consistent with national guidelines & $(5 \%)$ \\
( $\mathrm{n}=418$ ) & 2 \\
According to HIV type & 4 \\
HIV-1 on PI regimen in first line & \\
HIV-2 or dual on NNRTI & 16 \\
According to hemoglobin level & \\
Patient with anemia (<8 $\mathrm{g} / \mathrm{dl})$ on Zidovudine & \\
\hline
\end{tabular}

Finally, 1050 out of the 1659 tested patients $(63.3 \%)$ were lost to follow-up before antiretroviral treatment initiation, mainly because of the remoteness of the clinics where they were referred to, and the impossibility to perform the pre-treatment laboratory tests daily in the two laboratories of the region. Reduced number of health facilities providing care for PLWHA in this largest region requiring them to make long journeys to access these structures. In reality, the main reason for this high rate of attrition is the context of civil war in Côte d'Ivoire, which forced people to reduce their trips for security reasons. Attendance in health facilities decreased in this region during this period. The involvement of community health workers for the active search of the lost to follow up patients would improve the retention rate of patients in care. Patten et al. showed in the Khayelitsha area in South Africa that the introduction of a point-of-care CD4 test improved access to laboratory tests, which rose from $67 \%$ to $90 \%$ [15]. There is currently a renewed interest in these new rapid diagnostic tools in resourcelimited countries [16]. The inconsistency between ART prescriptions and national guidelines noticed in our study is partly due to lack of training and experience among nurses and midwives to whom this task is delegated in remote areas where physicians are just a few. $A$ prospective study in the current post-crisis context would better assess the cascade of care for HIV positive patients, and rates of loss to follow up and retention in care in this rural region.

\section{CONCLUSION}

Our study reveals high attrition rates (63.3\%) between screening and antiretroviral treatment initiation in this rural region of the north-central part of Côte d'Ivoire. The improvement of the quality of care for people living with HIV requires training and/or regularly upgrading healthcare workers, introducing "point of care" CD4 testing, and particularly adopting the "test and treat" strategy so as to reduce these high attrition rates.

\section{ACKNOWLEDGMENTS}

This study was presented as poster at the 16th National Infectious Diseases Meeting, 7-9 June, 2016, Lille, France.

We are grateful to patients and all the medical staff, physicians, nurses and midwives of the 
two health districts for getting involved in patient care.

\section{Declaration of conflicting interests}

The authors declare that they have no conflict of interest.

Dr. Patrick Coffie for the translation of the manuscript.

\section{Financial disclosure}

No financial support was received.

\section{REFERENCES}

1- UNAIDS Program. Access to drugs. UNAIDS Technical Update. In: UNAIDS Best Practice Collection. UNAIDS ed, Geneva, October 1998.

2- The Global Fund To Fight AIDS, Tuberculosis and Malaria. The Global Fund to Fight AIDS, Tuberculosis and Malaria announces first grants: commits up to $\$ 616$ million over two years for prevention and treatment. Disponible sur: http://www.globalfundatm.org

3- The United States President's Emergency Plan for AIDS Relief. Disponible sur: http://www.PEPFAR.gov

4- Eholié SP, Tanon KA, Folquet-Amorissani M, et al. Bilan de l'accès aux antirétroviraux en Côte d'Ivoire. Med Trop 2009; 69:520-524.

5- Moh R, Danel C, Messou E, et al. Incidence and determinants of mortality and morbidity following early antiretroviral therapy initiation in HIV-infected adults in West Africa. AIDS 2007 ; 21 : 2483-91.

6- WHO. Traitement antirétroviral de l'infection à VIH chez l'adulte et l'adolescent en situation de ressources limitées: vers un accès universel: recommandations pour une approche de santé publique. - Version 2006.

7- WHO. Antiretroviral therapy for HIV infection in adults and adolescents: recommendations for a public health approach. 2010 revision. Geneva: World Health Organization; 2010. pp. 1-359 Available from http://whqlibdoc. who.int/publications/2010/9789241599764_eng.pdf

8- Nosyk B, Montaner JSG, Colley G, et al. The cascade of HIV care in British Columbia, Canada, 1996-2011: a population-based retrospective cohort study. Lancet Infect Dis 2014; 14: 40-49

9- Sow PS, Otieno LF, Bissagnene E, et al. Implementation of an antiretroviral access program for HIV-1-infected individuals in resourcelimited settings: clinical results from 4 African countries. J Acquir Immune Defic Syndr 2007; 44 : 262-7.

10-Zannou DM, Kindé-Gazard D, Vigan J, et al. Clinical and immunological profile of HIV infected patients in Cotonou, Benin. Méd Mal Infect 2004; 34: 225-228.

11-Mahy S, Duong M, Huraux J-M, and al. Mesure de l'efficacité et de l'observance du traitement antirétroviral chez des patients infectés par le VIH au Cameroun. Méd Mal Infect 2011; 41:176-180.

12-Bashi J, Balestre E, Messou E, et al. Time trends in demographic and clinical characteristics of adult patients on HAART initiation in West Africa. Med Mal Infect 2010; 40 (8):449-455.

13-Govindasamy D, Meghij J, Negussi EK, et al. Interventions to improve or facilitate linkage to or retention in pre-ART (HIV) care and initiation of ART in low- and middle-income settings - a systematic review. J Int AIDS Soc 2014; 17(1): 19032.

14-ONUSIDA. 90-90-90. Une cible ambitieuse de traitement pour aider à mettre fin à l'épidémie du sida. Genève, 2014; 38 p.

15-Patten GE, Wilkinson L, Conradie K, et al. Impact on ART initiation of point-of-care CD4 testing at HIV diagnosis among HIV-positive youth in Khayelitsha, South Africa. J Int AIDS Soc 2013; $16: 18518$

16-Rowley CF. Developments in CD4 and viral load monitoring in resource-limited settings. Clin Infect Dis 2014; 58(3):407-412. 